А. В. Дедухно

\title{
КОМУНІКАТИВНО-ПРАГМАТИЧНІ ТА СТРУКТУРНО-СЕМАНТИЧНІ ХАРАКТЕРИСТИКИ ПЕРФОРМАТИВНОГО АКТУ ПРОХАННЯ
}

\footnotetext{
Дедухно A.В. Комунікативно-прагматичні та структурно-семантичні характеристики перформативного акту прохання.

У статті досліджуються комунікативно-прагматичні та структурно-семантичні особливості українського перформативного акту прохання. Зазначено його класифікаційні характеристики та місце серед споріднених з ним семантичних різновидів - благання, запрошення, заклинання тощо. Зазначено умови успішності, проаналізовано сполучувальні потенції, визначено повну синтаксичну та модифіковані форми.
}

Ключові слова: прохання, перформатив, екзерситив, реквестив, валентність.

Дедухно А.В. Коммуникативно-прагматические и структурно-семантические характеристики перформативного акта просьбы.

В статье исследуются коммуникативно-прагматические и структурно-семантические особенности украинского перформативного акта просьбы. Указаны классификационные характеристики и его место среди родственных семантических видов - мольба, приглашение, заклинание. Указаны условия успешности, проанализированы сочетательные потенции, описаны полная синтаксическая и модифицированные формы.

Ключевые слова: просьба, перформатив, экзерсетив, реквестив, валентность.

Dedukhno A.V.Communicative-pragmatic and structural-semantic characteristics of performative act of apologizing.

Lingvopragmatic and structural-semantic characteristics of performative act of apologizing and its functional synonyms is the aim of the article. The conditions of effectiveness are proposed, typical and nontypical performative representations are analyzed, the establishers' role of such structures are given in the article.

Key words: performativ, the speech act, apologizing, typical and non-typical performative apologizing. 
Теорія перформативності, сформувавшись у логіці, дала поштовх для появи нових напрямів у розвитку інших наук, зокрема напряму 3 лінгвопрагматики в мовознавстві. Дана стаття присвячується дослідженню одному 3 різновидів спонукальних актів, чи екзерситивів (за Дж. Остіном), - проханню, класичним індикатором якого є перформатив прошу: Прошу вашого дозволу; Прошу попередити мене. Здійснення таких актів відбувається, коли мовець намагається досягти чогось зусиллями співрозмовника, який може, але не зобов'язаний це зробити.

Вплив на адресата є глобальною метою, яку ставить собі мовець у процесі комунікації, і найбільше ця мета увиразнюється у спонуканнях. Мовленнєвий акт прохання як різновид спонукання досліджувався багатьма вченими (Дж. Сьорль, Д. Гордон, А. Вежбицька, Г. О. Золотова, Н. І. Формановська, В. С. Храковський, О. П. Володін, О. А. Бризгунова, О. П. Савельєва, О. В. Падучева, Т. В. Булигіна, Д. І. Шмельов, О. А. Романов та ін.). В україністиці в царині мовленнєвого етикету він розглядався в роботах Я. К. Радевич-Винницького [15, с. 180-181] та С. К. Богдан [6, с. 393-399], прагматичний аспект вживання актів прохання як експліцитних перформативів на матеріалі німецької та української мови аналізувався О.В. Попович [14]; прохання як імперативний жанр та результативність жанру прохання, успішність неуспішність якого залежить від мовної вправності адресанта вивчено в розвідках М. 3. Баліцької [3; 4]; семантико-прагматичний аналіз мовленнєвих актів прохання виконаний у розвідці Л. Р. Турик [18]; питання перекладу перформативної матриці «прохання» у політичному дискурсі розглядалося М. І. Ончуленко [13]; проблема опису в словниках прагматичних кліше на прикладі перформатива прошу в чеській та українській мовах поставлена в розвідці Н. Ф. Баландіної та М. І. Степаненка [1]; статусно фіксований мовленнєвий акт прохання в асиметричних ситуаціях спілкування вивчався М. М. Гринишиним [11]. Усе це свідчить про те, що проблема привертає увагу вчених, але ще не всі іiі аспекти висвітлено, зокрема, не досліджено граматичні й функціональні особливості прохання як перформативного акту, що й зумовлює актуальність роботи.

Метою нашої розвідки є дослідження структурно-семантичних i комунікативно-прагматичних характеристик прохання. Досягнення поставленої мети передбачає виконання таких завдань: з'ясувати суть мовленнєвого акту прохання та його функціональних синонімів: благання, мольба, заклинання, запрошення; описати класифікаційні особливості висловлювань-прохань; установити умови успішності; проаналізувати сполучувальні потенції перформативного дієслова прошу; визначити повну синтаксичну форму перформативного акту прохання та іiі модифікації; вказати на поширювачі перформативного ядра.

Об’єктом роботи є перформативний екзерситивний мовленнєвий акт прохання, предметом - його структурно-семантичні та комунікативнопрагматичні характеристики. 
Перформативний мовленнєвий акт прохання в класифікації Дж. Остіна входить до групи екзерситивів, у типології Дж. Сьорля - до групи директивів. Автор класифікації російських перформативних дієслів Ю. Д. Апресян прохання виділив в окрему групу, а Й. Крекич, навпаки, досліджуючи спонукальні перформативи, об'єднав в одну групу прохання, пропозиції, поради, попередження, пророкування, вимоги, накази, заборони, дозволи. «Польова природа категорії спонукальності дозволяе використовувати різноманітні варіанти свого структурування» [12, с. 125], тому можливе виділення різної кількості підтипів спонукання залежно від того, наскільки докладним буде членування. Так, більш детально класифікує спонукальні мовленнєві акти О. І. Беляєва, виділяючи, передусім на матеріалі англійської мови, прескриптивні (від англ. prescription наказ, постанова), сугестивні (від англ. suggest - пропонувати, радити) та реквестивні (від англ. request - прохання, вимога) мовленнєві акти, до складу останніх і входить прохання разом із благанням та запрошенням. Крім того, дослідниця виділяє в кожній з груп так звані ядерні i периферійні (інваріантні) види. Так, у групі реквестивів ядерним $\epsilon$ мовленнєвий акт прохання, а благання і запрошення - варіанти прохання. При цьому дослідниця вказує, що деякі мовленнєві акти можуть суміщати ознаки різних груп, наприклад, запрошення суміщає ознаки сугестивів i реквестивів, оскільки каузована дія є бажаною для мовця і приємною або корисною для адресата [5].

Інша позиція на класифікацію спонукальних мовленнєвих актів належить Н. I. Формановській, яка, спираючись на типологію О. І. Беляєвої, виділяє групи спонукальних актів за ознакою соціального статусу мовців і за ознакою корисності дії: ін'юнктиви (від англ. injunction- постанова, наказ), або прескриптивні мовленнєві акти, адвісиви (від англ. advise - радити, консультувати, повідомлювати), реквестиви (прохання, благання, заклинання) [20]. Порівняння цих класифікацій засвідчує їх неоднорідність. Вочевидь, це пояснюється різними критеріями, що враховуються при класифікації спонукальних актів та особливостями тієї мови, одиниці якої власне і класифікуються.

Оскільки ситуації спонукання різноманітні за прагматичним контекстом, деякі лінгвісти виділяють не групи, а види спонукання 3 притаманними їм семантико-прагматичними й соціально-ситуативними ознаками. Так, Ц. Саранцацрал виділяє соціально зумовлені мовленнєві акти (наказ, попередження, заборона, вимога, прохання) і соціально незумовлені акти (порада, пропозиція тощо) [16].

Орієнтуючись на словникові тлумачення предикатів 3 інтенцією прохання: просити - звертатися 3 проханням до кого-небудь, домагатися чогось; спонукати кого-небудь зробити, виконати щось [ВТССУМ, с. 1167]; благати - наполегливо, невідступно, ласкаво просити [ВТССУМ, с. 86]; молити - дуже просити, благати [ВТССУМ, с. 684]; 
заклинати - настійно прохати, благати про що-небудь [ВТССУМ, с. 395] (одне із значень); запрошувати - просити прибути куди-небудь, до когось із певною метою [ВТССУМ, с. 416], ми можемо їх сукупно віднести до реквестивів, оскільки усі вони включають сему «просити».

Заслуговує на увагу 3 погляду лінгвопрагматики класифікація О.О. Філатової, у якій ураховано такі фактори для визначення типів спонукальних ситуацій: наявність свободи вибору в адресата (категоричні, некатегоричні мовленнєві акти), фактор зацікавленості, фактор статусу, фактор виконавця, фактор нормативності, фактор оточення, фактор зумовленості [19]. До групи реквестивів включено такі спонукальні акти: прохання, благання, заклинання, прохання про пораду, прохання про дозвіл, упрошування.

Угруповання російських мовленнєвих актів М. Я. Гловинської передбачає підгрупу під назвою «прохання», у яку, крім інших вказаних вже дієслів, віднесені й апелювати та звертатися (з проханням), позначені авторкою як перформативи [9, с. 180]. Умови успішності мовленнєвого акту прохання сформовано багатьма ученими $[2 ; 9 ; 10 ; 17 ; 21 ; 22]$. Ми лише узагальнимо наявні здобутки:

1) мовець бажає здійснення дії / отримання чогось;

2) мовець знає, що адресат спроможний задовільнити його бажання;

3) мовець правомірний звернутися до адресата;

4) мовець усвідомлює, що адресат не зобов'язаний виконувати його бажання;

5) тому він невпевнений у результаті.

Одна 3 особливих характеристик прохання полягає в тому, що мовець виявляє адресату максимум «мовленнєвого сприяння» [20, с. 192] задля здійснення каузованої дії. Порушуючи проблему лексикографування перформативних висловлювань, Д. Войводич запропонував розглянути структури зі специфічними граматичними (синтактико-семантичними) зв'язками (передусім 3 керуванням), які відображають сполучувальні потенції кожного з перформативних дієслів. Таким чином, учений аналізує перформативні дієслова за двома типами валентностей: формальнооб'єктним (відмінковим) та предикативним на матеріалі сербської, російської та польської мов. Послуговуючись даними дослідженнями, українське перформативне дієслово прошу відносимо до угруповання «перформативи зі знахідним об'єкта» [7], тобто оформлення мовленнєвого акту прохання відбувається, базуючись на сполучувальності перформативного дієслова прошу і об'єкта-адресата, як правило, у знахідному відмінку 3 ознакою «аблативності», 3 одного боку, та поєднанням даного дієслова і каузованої проспективної дії-присудка в пропозиції висловлювання, з іншого [8]: Прошу вас, звільніть це місие.

Предикативна валентність передбачає взаємозв'язок темпоральних відношень з перформативними дієсловами, що дозволяє, у свою чергу, виділити «мобільні», які характеризуються вільним уживанням форм
(ㄱ А. В. Дедухно, 2011.
$-148-$ 
предиката в пропозиції 3 будь-якою темпоральною перспективою, та «немобільні» перформативи. Предикат прошу належить до немобільних, оскільки в його пропозиційній структурі присудок найчастіше виражається формами з ознакою футуральності: Просимо професора Холода розповісти про операцію тромбозу вени, яку він робив сьогодні (О. Гончар, «Крапля крові»), у той час як його вираження формами з ознаками претеритальності трапляються нечасто.

Повна форма перформативного мовленнєвого акту прохання реалізується у складнопідрядному з'ясувальному реченні зі сполучниками щзоб(u), якби за схемою Я / ми прошу / -имо, щзоб(и) ти / ви зробив / -ли. Наприклад: Отож я прошу, щзоб ви мене хоча б коротенько познайомили з історісю наукового $i$ суспільного поступу цивілізації... (Ю. Ячейкін, «Дивовижні пригоди капітана міжзоряного плавання Небрехи...»). Складнопідрядне речення прохання може «обростати» й іншими конструкціями, наприклад: Ти багато знаєщ людей, прошу, щзоб зробили громадську складчину на той друк... (О. Іваненко, «Марія»), Сдине, щуо я вас прошу: дотримуйтесь спокою (П. Загребельний, «Диво»).

У мовленні повна форма може модифікуватися. У спілкуванні спостерігаємо такі модифікації перформативного акту прохання:

1) акти прохання 3 перформативним дієсловом прошу можуть функціонувати у формі безсполучникового складного речення: Поперед изього прошу вас, допоможіть мені в изому ділі то порадою, то своїми словами, а потім скажете мені просто, чи можна мати яку надію? (I. Нечуй-Левицький, «Гетьман Іван Виговський»);

2) головна i підрядна частини можуть об'єднуватися в межах простого речення, тоді підрядна частина номіналізується (найчастіше у формі інфінітива чи інфінітивних сполук) й перетворюється у складений присудок: Я перша прошу вас зробити нам приємність $i$ залишитися довше щзе (О. Кобилянська, «Через кладку»); Прошу почекати внизу до другої години (У. Самчук, «Волинь») тощо;

3) у мовленні трапляються конструкції на зразок прошу + iмnератив дієслова, яке називає дію: Прошу вас, сідайте; Прошу вас, не хвилюйтеся; Прошу, зателефонуйте мені ввечері тощо, які можна назвати нейтральними. Більш чи менш інтенсифікованими є: Прошу, пробачте за запізнення; Прошу, будь-ласка, не затримуйте нас (Б. АнтоненкоДавидович «Смерть»). 3 погляду Н. І. Формановської, «у класі директивних мовленнєвих актів другим членом групи після: я прошу... виявляється імперативне висловлювання, при цьому імперативна форма буде створена від дієслова конкретної дії, тобто позначення майбутньої дії адресата, інтенційне ж значення висловлювання піде в імпліцитний спонукальний перформативний префікс» [20, с. 177]. Дійсно, висловлювання на зразок «прошу, з / робіть щзось» є багаточисельними серед спонукальних висловлювань. 
Категоричності висловлюванню надає поєднання перформативного дієслова 3 імперативом доконаного виду. Форми доконаного виду як категоричні імперативи виражають велике бажання мовця спонукати адресата зробити якусь дію й передбачають безумовне і негайне виконання наказу: Прошу тебе, зроби це; цю ж функцію виконують прислівникиінтенсифікатори на зразок негайно, швидко: Прошу негайно найти ї̈ або зробити нову, збийте з дощок (Б. Левін, «Видно шляхи полтавські»).

Перформативність висловлювань із проханням не втрачається, якщо типове перформативне дієслово прошу модифікується, наприклад, у сполучення з модальним дієсловом: хочу просити, хочу попросити, тим самим коригується і час дієслова. Модальні еквіваленти перформативів характеризуються тим чи іншим соціостилістичним відтінком у конкретних ситуаціях, вони $є$ більш «м'якими», некатегоричними, ввічливими. Висловлювання 3 дієсловом «хотіти» містять відтінок бажаності: Я хочу просити у вас допомоги, - продовжувала Шприндзя тим самим тоном (У. Самчук, «Чого не гоїть огонь»); Я хочу зараз просити ї̈ звільнення від кріпаџтва (І. Пільгук, «Грозовий ранок»). Форма майбутнього часу деякою мірою може втрачати значення майбутнього залежно від контексту: Попрошу затриматися; Попрошу не тикати (В. Дрозд, «Катастрофа»). Спосіб актів-прохань може бути умовним, виступаючи в ролі скоріше пом'якшувача спонукання: Хотіла б просити вас про інше (П. Загребельний, «Роксолана»), А хотів би з вами, хазяї, нащот житла... (У. Самчук, «Чого не гоїть огонь»).

У мовленні трапляються конструкції прошу + іменник: прошу вибачення, прошу ваше замовлення тощо. Семантика іменника може відігравати неабияку роль у різних видах спонукання. Так, наприклад, поєднання прошу + іменник емоційної дії виражає власне прохання, та поєднуючись 3 іменниками на зразок вибачення, слова утворює стійкі словосполучення-формули мовленнєвого етикету. Висловлювання ж прошу тиші, прошу уваги виражають інтенцію наказу. Мовленнєвий акт прохання може передаватися й формою іменника: А прохання маю до хана єдине: нехай його вони не обкрадають воӥнів султана... (Ю. Мушкетик, «Яса»); $А$ до тебе прохання - купити їм халати $i$ гумові чоботи. Обносились зовсім, одне рам'я висить (Г. Тютюнник, «Вир»).

Мовленнєвий акт прохання зі значенням «не робити чогось» в інтересах мовця передбачає такі пресупозиції:

1) мовець бажає, щоб адресат не робив дію, яка може бути поганою для нього;

2) мовець висловлює це адресату, тому що хоче, щоб той не робив дію;

3) мовець усвідомлює, що адресат не зобов'язаний цього не робити;

4) мовець припускає, що адресат має намір зробити дію з певною метою або без розуміння того, що наслідки будуть неприпустимі для мовця;

5) тому мовець невпевнений у результаті. 
Наприклад, мовець просить не робити дію, яка тільки передбачається: Прошу вас, не відчиняйте вікно; Прошу тебе, не повертайся уночі; Богом прошу, не розповідай нікому тощо. Можлива ситуація, коли мовець просить припинити дію, яка вже здійснюється: Прошу тебе не палити в кімнаті. Просити ж не робити того, що інша людина не робить і навіть не збирається, - є неадекватним: Прошу, не сідай верхи на злого пса.

На функціональний характер перформативного акту прохання, як i інших спонукальних мовленнєвих актів, впливає наявність у їх структурі поширювачів:

a) інтенсифікаторів, представлених прикметниками: велике - маю велике прохання; прислівниками: дуже, ласкаво - дуже прошу, ласкаво прошу, Дуже прохаю вибачення, шановний професоре, але мушу запитати: який ви маєте емпіричний трунт для ваших многочінних тезів? (В. Винниченко, «Чорна пантера і білий медвідь»); Дуже прошу тебе розвідати, розпитати людей, дівчат, парубків, чи не чули чогось про Наталку (І. Пільгук, «Грозовий ранок»); Але я прошу про велику ласку!... Дуже прошу твоєї ласки! (Ю. Логвин, «Таємниця одного діаманта»); іншими словосполученнями: Коли ви того бажаєте, то я прошу вас од щирого серия (І. Нечуй-Левицький, «Хмари»); Христом-богом прошу, не нагадуй мені про те, Чіпко (Панас Мирний, «Хіба ревуть воли...»).

б) конкретизаторів, серед яких - звертання, адресативи та обставини. Так, 3 метою привернути увагу адресата і виявити в нього максимум гарних почуттів, мовець використовує ласкаві, ніжні чи шанобливі звертання: дорогенький, великий візирю, друже мій, Боже мій - Ой Себастіане дорогенький, богом прошу тебе, не вибивай душу із тіла, не запогуби, не прибий мого нездалого, мого зеленоголового! (М. Стельмах, «Щедрий вечір»); Великий візирю, я прошу, щоб мені Порта не заважала різними фірманами розпоряджатися долею Криму (Р. Іваничук, «Мальви»); Боже мій, боже! Одного тільки в тебе прошу: однієї смерті молю! (Панас Мирний, «Хіба ревуть воли...»); адресативи: Прошу вас, не витримала-таки Ольга Петрівна, - прошу вас пояснити, у чім? (Б. Олійник, «Леся»), повтор тут виконує функцію інтенсифікації прохання; обставини: У иеей пізній час прошу твоєї допомоги; I грошей не дають, прохаю, як милостині, хоча б копіювальників розрахувати (Б. Левін, «Видно шляхи полтавські»).

Отже, ми дослідили структурно-семантичні та функціональні характеристики перформативного акту прохання в українській мові. Проаналізовано класифікаційні особливості, визначено умови успішності, сполучувальні потенції предиката прощу, описано повну реченнєву структуру та їі модифікації. На майбутнє заслуговує на увагу дослідження семантичних синонімів прохання - благання, заклинання, запрошення. 


\section{Література}

1. Баландіна Н.Ф. До проблеми опису етикетних перформативів у словниках (чесько-українські паралелі) / Н.Ф. Баландіна, М.І. Степаненко. - Eslavistica Complutense, 2007. - № 7. - С. 63 - 76.

2. Баландіна Н.Ф. Функції і значення чеських прагматичних кліше в комунікативному контексті : [монографія] / Н. Ф. Баландіна. - К. : АСМI, 2002. - 332 с.

3. Баліцька М. 3. Жанр мовлення прохання як об’єкт вивчення в іншомовній аудиторії / М. 3. Баліцька // Вісник Львівського ун-ту : Серія філологічна. - 2008. - Вип. 3. - С. 325 - 328.

4. Баліцька М. 3. Роль адресанта в реалізації мовленнєвого жанру прохання / М.3. Баліцька // Вісник Львівського ун-ту : Серія філологічна. - 2006. - Вип. 38. - Ч. II. - С. 130 - 134.

5. Беляева Е. И. Грамматика и прагматика побуждения : Английский язык / Е. И. Беляева. - Воронеж ВГУ, 1992. - $168 \mathrm{c}$.

6. Богдан С. К. Мовний етикет українців : традиції і сучасність / С. К. Богдан. - К. : Рідна мова, 1998. $-475 \mathrm{c}$.

7. Войводич Д. О валентности перформативных глаголов в славянских языках / Д. Войводич // Зборник Матице српске за славистику свеска 56-57. - Београд : Технологије-издавашто-агенција ЈАНУС, 1999. - С. $71-94$

8. Войводич Д. Функционально-семантическое поле перформативности в славянских языках / Д. Войводич // Zbornik Matice srpske za slavistiku. - Београд, 2003. - C. 45-77.

9. Гловинская М.Я. Семантика глаголов речи с точки зрения теории речевых актов / М.Я. Гловинская // Русский язык в его функционировании. Коммуникативно-прагматический аспект. - М. : Наука, 1993. С. $158-218$.

10. Гордон Д. Постулаты речевого общения / Д. Гордон, Дж. Лакофф // Новое в зарубежной лингвистике. - Вып. 16 : Лингвистическая прагматика : Сборник / Общ. ред. Е.В. Падучевой. - М. : Прогресс, 1985. - С. $276-302$ с.

11. Гринишин М. М. Статусно фіксований мовленнєвий акт прохання (на матеріалі художньої прози Івана Франка) / М. М. Гринишин // Наукові праці : Науково-методичний журнал. - Т. 98. - Вип. 85. Філологія. Мовознавство. - Миколаїв : Вид-во ЧдУ ім. Петра Могили, 2009. - С. 9-13.

12. Изотов А. И. О семантическом картировании поля побудительности чешским и русским языками / А. И. Изотов // Язык. Сознание. Коммуникация. - М. : Макс Прес, 1998. - Вып. 4. - С. 125.

13. Ончуленко М. І. Переклад перформативної матриці «прохання» у політичному дискурсі / М. І. Ончуленко // Вісник СумДУ : Серія : Філологія. - 2007. - № 1.- Т. 2. - С. 145-149.

14. Попович О. В. Номінація ілокуції при вираженні прохання (на матеріалі німецької та української мови) / О. В. Попович // Іноземна філологія : Український науковий збірник. - Львів : ЛНУ імені Івана Франка, 2008. - Вип. 120. - С. 161-167.

15. Радевич-Винницький Я. К. Етикет і культура спілкування : Навчальний посібник / Я. К. РадевичВинницький. - [2-е вид., перероб. і доп.]. - К. : Знання, 2006. - 291 с.

16. Саранцацрал Ц. Речевые акты побуждения, их типы и способы выражения в русском языке : автореф. дисс. на соискание ученой степени докт. филол. наук. : спец. 10.02 .01 «Русский язык»/ Ц. Саранцацрал. - М., 1993. - 40 с.

17. Серль Дж. Р. Косвенные речевые акты / Дж. Сьорль // Новое в зарубежной лингвистике. Вып. 17. - Теория речевых актов : Сборник / Общ. ред. В.Ю. Городецкого. - М. : Прогресс, 1986. C. $195-222$.

18. Турик Л. Р. Семантико-прагматичний аналіз мовленнєвих актів прохання / Л. Р. Турик // Мова $\mathrm{i}$ культура (Науковий журнал). - К. : Видавничий Дім Дмитра Бураго, 2009. - Вип. 11. - Т. XII (124). C. 17-23.

19. Филатова Е. А. Побудительные высказывания как речевые акты в современном русском языке : дис. ... докт. филол. наук. : 10.02.01 / Елена Алексеевна Филатова. - М., 1997. - 243 с.

20. Формановская Н. И. Коммуникативно-прагматические аспекты единиц общения / Н. И. Формановская. - М. : Ин-т рус. яз. им. А. С. Пушкина, 1998. - 291 с.

21. Flídrová H. Výzvové komunikáty / H. Flídrová // Sborník jazykovĕdných a literárněvědných prací. Praha : Státní pedagogiské nakladatelství, 1981. - S. 5-22.

22. Grepl M. Skladba češtiny / M. Grepl, P. Karlík. - Olomous : Votobia, 1998. - 503 s.

\section{Словники}

1. Великий тлумачний словник сучасної української мови (з дод., допов. та CD) / [уклад. і голов. ред. В. Т. Бусел]. - К. ; Ірпінь : ВТФ «Перун», 2009. - 1195 с. : іл. 